\title{
オフィスの温熱環境が作業効率及び電力消費量に与える総合的な影響 THE TOTAL EFFECT ON PERFORMANCE AND ENERGY CONSUMPTION CAUSED BY OFFICE'S THERMAL ENVIRONMENT
}

\section{多和田友美 ${ }^{*}$, 伊香賀 俊治**, 村上周 三***, 内田匠子****, 上田 悠***** Tomomi TAWADA, Toshiharu IKAGA, Shuzo MURAKAMI, Shoko UCHIDA and Haruka UEDA}

\begin{abstract}
Various researches highlight that indoor air quality affects performance of workers in offices. Although good indoor air quality improves work performance, it also increases energy consumption. In this study, we achieved a field survey in a real office in order to investigate the relationship between thermal environment, productivity, and energy consumption. In addition to the monitoring of indoor environmental quality and energy consumption, subjective experiments were conducted. In order to evaluate subjective performance, workers and students responded to questionnaires, and to evaluate objective performance, students simulated three types of office works. By calculating room temperature and worker's subjective performance, we demonstrate the correlation between room temperature and worker's performance $\left(\mathrm{R}^{2}=0.22, \mathrm{p}<0.01\right)$. Results show that the room temperature that maximizes worker's performance was $25.7^{\circ} \mathrm{C}$.
\end{abstract}

Keywords : Productivity, Work Performance, Thermal Environment, Energy Consumption, Subjective Experiment, Field Survey 知的生産性，作業効率，温熱環境，エネルギ一消費量，被験者実験，現地調査

\section{1. はじめに}

近年、高度化した現代社会では室内空間において健康性、快適性 に加えさらに “知的生産性”の高い室内環境が要求されると言われ ている ${ }^{1)}$ 。この知的生産性に関する検討として、執務空間における 室内環境の質が作業効率に及ぼす影響や学習環境が学習効率に及ぼ 寸影響の定量化が試みられている。村上ら ${ }^{2)}$ は実験室実験及び現地 実測の実施により、教室の温熱・空気環境が学習効率並びに学習意 欲に及ぼす影響を検討している。羽田ら ${ }^{3)}$ は、執務空間における検 討として、夏季室温緩和設定オフィスにおける実測調查により、周 辺空気温度及び周辺 $\mathrm{SET} *$ が $25^{\circ} \mathrm{C}$ 以上の時、空気温度が高いほど主 観作業能力は低下寸ると報告している。欧米では既に多くの研究が なされており、Seppänen らは、オフィス、教室、実験室で行われた 24 の既往研究の要約により室内温度と相対的な作業効率の関係式 を ${ }^{4)} 、 9$ の既往研究の要約により換気回数と相対的な作業効率の関 係式を ${ }^{5)}$ 、それぞれ提案している。温熱・空気環境といった室内環 境の質が知的生産性に及ぼす影響は多大であり、執務空間において 個人の作業効率向上は組織経営にも大きな便益をもたらすため ${ }^{6}$ 、 作業効率を最大化する執務空間の提供が望まれる。

一方、このような高水準な室内環境の形成は、空調用電力消費量 の増大を招くことが指摘される。京都議定書の発効により、我が国 は 2008-2012 年における年平均温室効果ガス排出量を 1990 年レベ ルより 6\%削減させるという公約を批准した ${ }^{77}$ が、2007 年には 1990 年比で $45 \%$ も増加しており ${ }^{8)}$ 、温室効果ガス排出量の削減が喫緊の
課題となっている。地球環境問題が深刻化する現在、作業効率の向 上のみならず、電力消費量削減への配慮が重要である。

そこで本研究では、室内環境の質並びに電力消費量を、空間分布 も考慮して詳細に測定しているオフィスにおいて被験者実験を行う ことで、温熱環境と作業効率及び電力消費量の関係の検討を行う。 このオフィスを対象とすることで、これまで困難とされてきた、室 内環境の質と作業効率・電力消費量の関連付けを行うことが可能と なる。ここで、室内環境の質が作業効率・電力消費量に与える影響 を総合的に検討するためには、作業効率・電力消費量の評価尺度を 揃えることが必要となる。多くの既往研究では、作業効率と電力消 費量の評価尺度を金額換算值で置き換えている ${ }^{9) ~ 12) 。 ま た 、 R E H V A ~}$ は投資や建物運用方法と知的生産性向上による潜在的便益の比較の ためのライフサイクルコストの計算手順を提案している ${ }^{13)}$ 。本研究 では、実測により得られた作業効率やエネルギー消費量データを用 い人件費・エネルギー費による金額換算を行うことで経済性を最 良にする室内温度を検討する。

\section{2. 現地調査・被験者実験の概要}

本研究では、室内の温熱・空気環境ならびに電力消費量を詳細に 測定しているオフィスにおいて 4 週間の現地調査を行った。1 週間 毎に室内温度及び $\mathrm{CO}_{2}$ 濃度をそれぞれ変化させ、各週の水曜日に被 験者実験を実施した。同オフィス内において社員およびアルバイト により募集した学生を被験者とする被験者実験を行うことで、2 種

\footnotetext{
本論文は，本研究に関する既発表論文である参考文献15），16），18）に新たな知見を加え，加筆・修正したものである。

* 慶応義塾大学大学院 大学院生 Graduate Student, Keio Univ.

** 慶応義塾大学理工学部 教授·工博

*** 建築研究所 理事長.工博

$* * * *$ 森ビル(侏)

***** (株)山武

Prof., Faculty of Science and Technology, Keio Univ., Dr. Eng.

Chief Executive, Building Research Institute, Dr. Eng.

Mori Building Co., Ltd.

Yamatake Corporation
} 
類の被験者実験を等しい環境下で同時に行った。社員を対象とした 被験者実験により心理量の再現及びデータ数の確保が、学生を対象 とした被験者実験により客観作業の評価及び主観評価と客観評価の 整合性の検討が可能となる。

\section{3. 社員を対象とする被験者実験の概要}

\section{1 期間 ·場所・被験者}

実験は、2007/7/9〜8/3に 7 階建てのオフィスビルの 4F 並びに 5F を対象に行った。レイアウトを図 1 に示寸。また社員を対象とした 被験者実験法、4F 150 名(男性 118 名、女性 32 名)、 5 F 205 名(男性 164 名、女性 41 名) の計 355 名の社員を対象に、曜日や時間帯の影 響を極力排除するため、毎週水曜日注 ${ }^{1)}$ の $7 / 11 、 18 、 25 、 8 / 1$ の 4 日 間行った。いずれのフロアも床面積 $1555.2 \mathrm{~m}^{2}$ で、人員密度は 4F 0.10 人 $/ \mathrm{m}^{2} 、 5 \mathrm{~F} 0.13$ 人 $/ \mathrm{m}^{2}$ であり、空間的にほぼ同じものとみなす。着衣 量は目視により 0.5 clo と判断し、代謝量は $1.1 \mathrm{met}$ とした。

\section{2 実験条件}

室内温度 $26^{\circ} \mathrm{C}$ 、室内湿度成り行き、室内 $\mathrm{CO}_{2}$ 濃度 $600 \mathrm{ppm}$ 程度と いう通常通りの運用状況を基本として設定した被験者実験の環境設 定条件を表 1 に示寸。室内温度、 $\mathrm{CO}_{2}$ 濃度、被験者群をパラメータ とした $2 \times 2$ のクロスオーバーデザインとした。各条件とも 1 週間の 制御を行った。ここで、 $28^{\circ} \mathrm{C} や 1000 \mathrm{ppm}$ の条件は、研究のために期 間限定で設定したものである。

\section{3 測定項目}

\section{(1) 物理環境の測定項目}

物理環境の測定点を図 1 に、測定項目及び測定機器を表 2 にそれ ぞれ示す。対象オフィスでは、各階において図 1 ○位置の 12 点で、 常設の温度センサにより床上 $1.1 \mathrm{~m}$ での空気温度の時系列測定を行 っている。また、相対湿度と $\mathrm{CO}_{2}$ 濃度は空調機単位である図 1 の点 線で区切られた 4 ゾーンで測定しており、各ゾーンからの戻り空気 中の相対湿度と $\mathrm{CO}_{2}$ 濃度の平均值を図 1 口位置の機械室にて時系 列測定している。

これら常設のセンサによる測定に加え、図 1 位置の室中央部で、 座位高さである床上 $1.1 \mathrm{~m}$ での空気温度及び、放射温度、風速を時 系列で測定した。空気温度の測定には T-熱電対を使用し、放射温度 の測定には $\mathrm{T}$-熱伝対及びグローブ球を使用、風速の測定にはクリモ マスター風速計(無指向性) を使用した。また、日射の影響を受けや 寸い空際の図 1 ○位置の 2 点にて、床上 $1.1 \mathrm{~m}$ での空気温度・放射 温度を時系列で測定した。さらに、常設の温度センサとの整合性の 確認注 2)のため、図 1 ○との対応している位置の常設の温度セン サ横にて、床上 $1.1 \mathrm{~m}$ での空気温度・放射温度の測定を行った。図 1 ○位置の空気温度・放射温度の測定には、温湿度データーロガー及 びグローブ球を使用した。粉塵濃度は $\mathrm{CO}_{2}$ 濃度の設定条件が $600 \mathrm{ppm}$ の 7/11 と、1000ppmの8/1 にそれぞれ 1 回ずつ、図 1 A位置の室中 央部にてデジタル粉塵計を用い、測定した。暗騒音は 7/11の社員が 不在になる勤務時間後に、騒音計により図 $1 \boldsymbol{\Delta}$ 位置の室中央部にて 測定した。机上面照度は7/11、7/25 の勤務時間中に、デジタル照度 計を用い図 1 ×位置にて測定した。

\section{(2) 作業効率の測定方法}

社員の作業効率は、アンケートによる主観評価により測定した。 国土交通省の知的生産性検討委員会にて検討されている

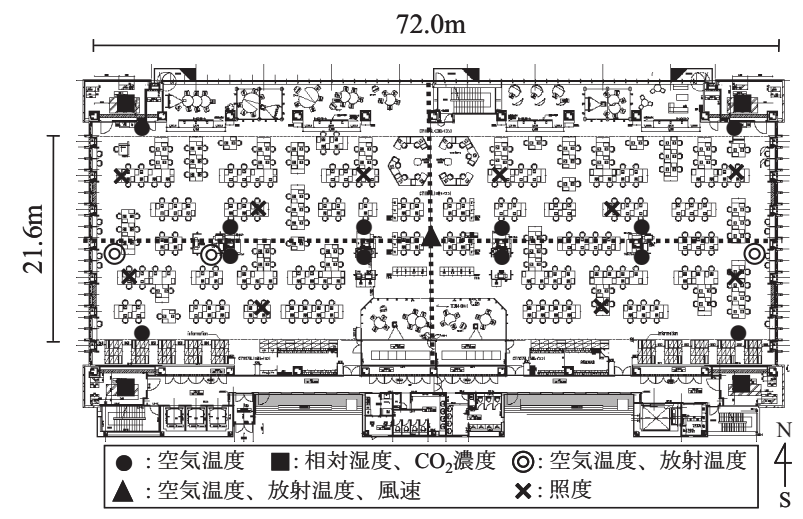

図 1 オフィスのレイアウトと物理環境の測定点 $(4 \mathrm{~F} \cdot 5 \mathrm{~F}$ 同様 $)$ 表 1 実験条件

\begin{tabular}{|c|c|c|c|c|c|}
\hline \multirow[b]{2}{*}{ 期間 } & \multirow[b]{2}{*}{$\begin{array}{c}\text { アンケート } \\
\text { 実施日 }\end{array}$} & \multicolumn{2}{|c|}{$4 \mathrm{~F}$} & \multicolumn{2}{|c|}{$5 \mathrm{~F}$} \\
\hline & & $\begin{array}{l}\text { 室内 } \\
\text { 温度 } \\
\left.{ }^{\circ} \mathrm{C}\right]\end{array}$ & $\begin{array}{c}\mathrm{CO}_{2} \text { 濃度 } \\
{[\mathrm{pmm}]}\end{array}$ & $\begin{array}{l}\text { 室内 } \\
\text { 温度 } \\
\left.{ }^{\circ}{ }^{\circ} \mathrm{C}\right]\end{array}$ & $\begin{array}{c}\mathrm{CO}_{2} \text { 濃度 } \\
{[\mathrm{ppm}]}\end{array}$ \\
\hline $7 / 9 \sim 13$ & $7 / 11$ (水) & 25 & \multirow{2}{*}{600} & 28 & \multirow{2}{*}{600} \\
\hline $7 / 16 \sim 20$ & $7 / 18$ (水) & 28 & & 25 & \\
\hline $7 / 23 \sim 27$ & $7 / 25$ (水) & 25 & \multirow{2}{*}{1000} & 28 & \multirow{2}{*}{1000} \\
\hline $7 / 30 \sim 8 / 3$ & $8 / 1$ (水) & 28 & & 25 & \\
\hline
\end{tabular}

表 2 物理環境の測定項目・測定機器

\begin{tabular}{|c|c|c|}
\hline & 測定項目 & 測定機器 \\
\hline - & 空気温度 & $\begin{array}{l}\text { 無線型温度検出器ネオセンサワイヤレス TY7063Z } \\
\text { (山武) }\end{array}$ \\
\hline \multirow[t]{2}{*}{ [ } & 相対湿度 & 挿入型温湿度発信機 HTY7803C (山武) \\
\hline & $\mathrm{CO}_{2}$ 濃度 & 挿入型 $\mathrm{CO}_{2}$ 濃度発信機 $\mathrm{CY} 8100 \mathrm{C}$ (山武) \\
\hline (a) & $\begin{array}{l}\text { 空気温度 } \\
(1.1 \mathrm{~m}) \\
\text { 放射温度 } \\
(1.1 \mathrm{~m})\end{array}$ & $\begin{array}{l}\text { 温湿度データーロガー TR-71U (T\&D) } \\
\text { グローブサーモメータ石川式 080340-150 (柴田科学) }\end{array}$ \\
\hline \multirow[t]{3}{*}{$\boldsymbol{\Delta}$} & $\begin{array}{l}\text { 空気温度 } \\
(1.1 \mathrm{~m}) \\
\text { 放射温度 } \\
(1.1 \mathrm{~m}) \\
\text { 風速 }(1.1 \mathrm{~m})\end{array}$ & $\begin{array}{l}\text { T-熱電対 T-6F(二宮電線工業) } \\
\text { グローブサーモメータ石川 } 080340-150 \text { (柴田科学) } \\
\text { クリモマスター風速計 無指向性 6533 (KANOMAX) } \\
\text { データーロガー NR-1000 (KEYENCE) }\end{array}$ \\
\hline & 粉塵濃度 & デジタル粉塵計 LD-3B (柴田科学) \\
\hline & 暗騒音 & 普通騒音計 NL-21（RION） \\
\hline$x$ & 机上面照度 & 照度計 T-10 (KONICA] \\
\hline
\end{tabular}

表 3 空調設備における測定項目

\begin{tabular}{c|c}
\hline 設備 & \multicolumn{1}{c}{ 測定項目 } \\
\hline \multirow{2}{*}{ 空調機 } & (1) 冷水積算熱量 $[\mathrm{MJ}]$ \\
\cline { 2 - 2 } & (2) 送風機電力量 $[\mathrm{kWh}]$ \\
\hline \multirow{2}{*}{ 冷温水熱源設備 } & (3) 冷水積算熱量 $[\mathrm{MJ}]$ \\
\cline { 2 - 3 } 送風機(換気ファン) & (4) 冷温水生成に消費する電力量 $[\mathrm{kWh}]$ \\
\hline
\end{tabular}

SAP(Subjective Assessment of workplace Productivity) ${ }^{14)}$ をとにアン ケートを作成し、通常通りの業務を行った後、16 時頃に Web 上で 回答させた。アンケート項目中の、仕事のし易さの妨げとなってい る要因 (1.光環境 2. 温熱環境 3. 空気環境 4. 音環境 5. 空間環境 6.人 間関係 7.職務内容 8.モチベーション 9.特になし) のうち、上位環 境要因 $(=1 . \sim 5$.$) の改善による作業の予想向上率[\%] を回答させ、$ 主観評価に基づく作業効率 $[\%]=100 /(100+$ 予想向上率) により算出 した。

\section{（3）電力消費量の測定 · 算出方法}

対象施設では、冷温熱源設備にて施設全体で使用する冷温熱を生 成している。生成した冷温熱を各階に設置された空調機に分配し、 取り込んだ外気の冷却又は加熱に用い、その空気を室内一搬送する。 
対象オフィスである $4 \mathrm{~F} 、 5 \mathrm{~F}$ には、空調機( $\mathrm{AHU})$ が各階 4 機ずつ設 置されており、各機において 1 フロアの 4 分の 1 の空調を行ってい る。 $4 \mathrm{~F} ・ 5 \mathrm{~F}$ の空調機は図 1 の位置に配置されている。

空調設備における電力消費量の測定項目を表 3 に示す。表 3 の項 目の測定結果を用い、空調設備の電力消費量を「冷温熱源設備の電 力消費量」注 3$) 、 「$ 空気搬送用の電力消費量」注4)に分けて算出した。 3.4 統計解析方法

作業効率(主観評価ならびに客観評価)の環境間比較には、等分散 を仮定し、有意水準 $5 \%$ で対応のある注 ${ }^{5)} \mathrm{t}$ 検定を行う。

\section{4. 学生被験者を対象とする被験者実験の概要}

社員のアンケートによる作業効率の客観性を補完するために、社 員の業務を模擬した作業をアルバイトにより募集した学生被験者を 対象に実施した。

\section{1 期間 - 場所 · 被験者}

学生被験者による実験は 4F、5F のオフィスの室中央部の空きス ペースを使用し社員がアンケートを行う同日に行った。被験者は $4 \mathrm{~F}$ 6 名 (男性 6 名)、 $5 \mathrm{~F} 6$ 名 (男性 4 名、女性 2 名) の計 12 名の大学生・ 大学院生とした。学生被験者には、正当な報酬に加え、作業に取り 組む動機のレベルを一定に保つため、成績上位者に対しボーナスを 支払った。

\section{2 作業効率の測定方法}

アンケートによる主観評価に基づく作業効率の評価に加え、客観 評価に基づく作業効率の評価として校正作業注 6)、加算作業注 7)、夕 イピング作業注 ${ }^{8)}$ を課し、それぞれの回答数に対する正答数の割合、 つまり正答率を評価した。ここで、作業間の比較を行うために難易 度、習熟度を考慮し、正規化した正規化パフォーマンスを客観評価 に基づく作業効率とした。正規化は、3 種の作業それぞれの平均值 が 50、標準偏差が 10 になるように統一寸ることで行った。

\section{3 実験手順}

学生被験者の実験手順を図 2 に示す。学生被験者は 13 時にオフィ スに入室し、 5 分間の休㮩の後、15 分間安静にし、環境に十分曝露 した。その後、20 分間の校正作業、20 分間の加算作業を行い、休愨 後 45 分間のテキストタイピングを実施した。そして同一の作業を、 テキストタイピング、加算作業、校正作業と順番を入れ替えて行い、 最後に主観評価に基づく作業効率を申告するアンケートを行った。 アンケートは社員に実施したものと対応しており、学生被験者は紙 面で回答した。

\section{5. 物理環境の測定結果}

物理環境の測定結果を表 4 注 ${ }^{9}$ に示す。いずれの值も執務時間であ る 9 時〜 17 時の平均值である。全期間を通して、階平均室内温度は $4 \mathrm{~F}$ で $24.9^{\circ} \mathrm{C} \sim 27.5^{\circ} \mathrm{C} 、 5 \mathrm{~F}$ で $24.9^{\circ} \mathrm{C} \sim 27.7^{\circ} \mathrm{C}$ であった。放射温度は室 内温度の変化に伴い変化していた。風速は $4 \mathrm{~F}$ で平均 $0.08( \pm 0.01) \mathrm{m} / \mathrm{s}$ 、 $5 \mathrm{~F}$ で平均 $0.08( \pm 0.03) \mathrm{m} / \mathrm{s}$ と等しく、相対湿度は $4 \mathrm{~F}$ で平均 $58( \pm 4) \%$ 、 $5 \mathrm{~F}$ で平均 $60( \pm 4) \%$ とほぼ等しかった。 $\mathrm{CO}_{2}$ 濃度は $4 \mathrm{~F}$ で $710 \mathrm{ppm}$

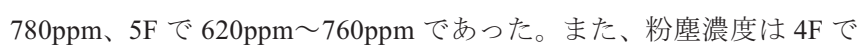
$0.009 \mathrm{mg} / \mathrm{m}^{3} 、 5 \mathrm{~F}$ で $0.007 \mathrm{mg} / \mathrm{m}^{3}$ 、騒音は $4 \mathrm{~F}$ で $50.8 \mathrm{~dB} 、 5 \mathrm{~F}$ で $51.4 \mathrm{~dB}$ とほぼ等しかった。平均照度は $4 \mathrm{~F}$ で $6931 \mathrm{x} 、 5 \mathrm{~F}$ で $7851 \mathrm{x}$ であり、 $5 \mathrm{~F}$ が若干高めの結果であった。室内温度の測定結果にばらつきが見ら
(1) (2) (3)
(4) (1)
(5)
(1)
(5)
(1) (4) (3) (6)

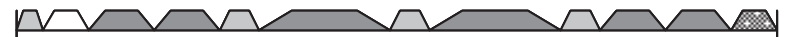

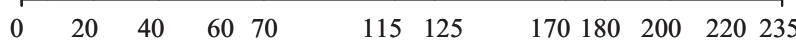
(1) 休鄎 (2) 安静 (3) 校正作業 (4) 加算作業

(5) タイピング作業 (6) アンケート

図 2 学生被験者の実験手順

表 4 物理環境の測定結果( 9 時 17 時 階平均)

\begin{tabular}{c|c|c|c|c|c|c}
\hline & $\begin{array}{c}\text { 測定 } \\
\text { 日 }\end{array}$ & $\begin{array}{c}\text { 室内温度 } \\
{\left[{ }^{\circ} \mathrm{C}\right]}\end{array}$ & $\begin{array}{c}\text { 放射温度 } \\
{\left[{ }^{\circ} \mathrm{C}\right]}\end{array}$ & $\begin{array}{c}\text { 風速 } \\
{[\mathrm{m} / \mathrm{s}]}\end{array}$ & $\begin{array}{c}\text { 相対湿度 } \\
{[\%]}\end{array}$ & $\begin{array}{c}\mathrm{CO}_{2} \text { 濃度 } \\
{[\mathrm{ppm}]}\end{array}$ \\
\hline & $7 / 11$ & $24.9 \pm 0.7$ & $25.2 \pm 0.3$ & $0.09 \pm 0.04$ & $63 \pm 3$ & $740 \pm 90$ \\
\cline { 2 - 7 } 4 & $7 / 18$ & $26.9 \pm 0.5$ & $27.2 \pm 0.3$ & $0.06 \pm 0.03$ & $57 \pm 4$ & $710 \pm 80$ \\
\cline { 2 - 7 } $\mathrm{F}$ & $17 / 25$ & $25.0 \pm 0.6$ & $25.4 \pm 0.4$ & $0.08 \pm 0.03$ & $56 \pm 2$ & $780 \pm 90$ \\
\cline { 2 - 7 } & $(2) 8 / 1$ & $27.5 \pm 0.4$ & $27.7 \pm 0.3$ & $0.08 \pm 0.03$ & $55 \pm 4$ & $780 \pm 90$ \\
\hline \multirow{3}{*}{5} & $7 / 11$ & $27.0 \pm 0.8$ & $26.8 \pm 0.3$ & $0.06 \pm 0.04$ & $64 \pm 2$ & $620 \pm 30$ \\
\cline { 2 - 7 } $\mathrm{F}$ & $7 / 18$ & $24.9 \pm 0.7$ & $25.1 \pm 0.3$ & $0.12 \pm 0.07$ & $61 \pm 2$ & $620 \pm 50$ \\
\cline { 2 - 7 } & $(2) 7 / 25$ & $27.7 \pm 0.4$ & $27.9 \pm 0.3$ & $0.06 \pm 0.05$ & $55 \pm 2$ & $760 \pm 70$ \\
\cline { 2 - 7 } & $(1) 8 / 1$ & $25.1 \pm 0.6$ & $25.6 \pm 0.4$ & $0.09 \pm 0.04$ & $58 \pm 3$ & $730 \pm 60$ \\
\hline
\end{tabular}

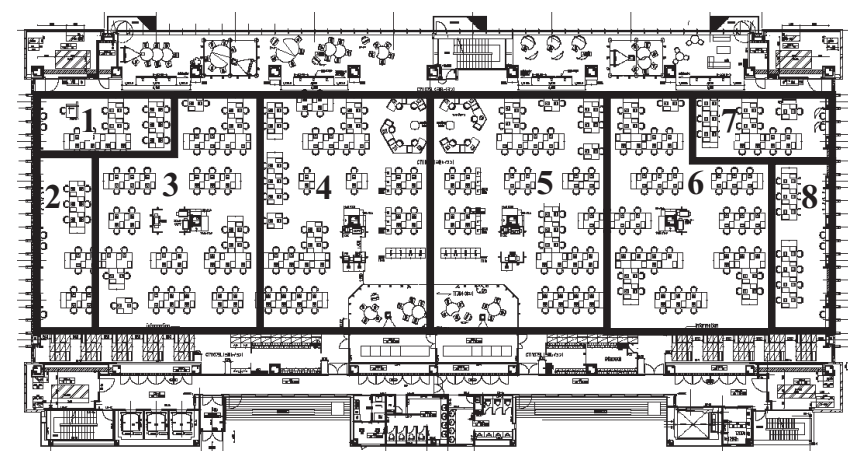

図 3 室温分布によるゾーン分け

表 5 ゾーン毎の室内温度の測定結果( 9 時〜17 時)

\begin{tabular}{c|c|c|c|c|c|c|c|c|c}
\hline & $\begin{array}{c}\text { 測定 } \\
\text { 日 }\end{array}$ & 1 & 2 & 3 & 4 & 5 & 6 & 7 & 8 \\
\hline \multirow{3}{*}{4} & $7 / 11$ & 25.2 & 25.3 & 25.2 & 25.1 & 25.4 & 25.2 & 24.0 & 23.7 \\
\cline { 2 - 10 } & $7 / 18$ & 27.5 & 27.3 & 27.2 & 26.9 & 26.9 & 27.4 & 26.1 & 26.3 \\
\cline { 2 - 10 } & $7 / 25$ & 25.1 & 25.5 & 25.2 & 25.0 & 25.4 & 25.1 & 24.3 & 23.9 \\
\cline { 2 - 10 } & $8 / 1$ & 27.4 & 27.3 & 27.1 & 27.0 & 27.9 & 27.9 & 27.7 & 27.8 \\
\hline \multirow{2}{*}{5} & $7 / 11$ & 26.9 & 26.2 & 27.1 & 27.9 & 27.6 & 27.5 & 26.9 & 25.6 \\
\cline { 2 - 10 } $\mathrm{F}$ & $7 / 18$ & 24.8 & 23.5 & 25.4 & 25.4 & 25.4 & 25.2 & 25.3 & 24.5 \\
\cline { 2 - 9 } & $7 / 25$ & 27.6 & 27.0 & 27.8 & 28.0 & 27.9 & 28.0 & 28.1 & 27.4 \\
\cline { 2 - 9 } & $8 / 1$ & 24.4 & 24.3 & 25.6 & 25.2 & 25.4 & 25.3 & 25.8 & 24.5 \\
\hline
\end{tabular}

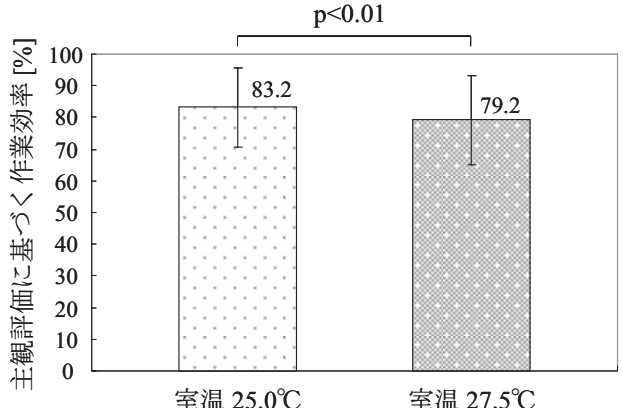

図 4 主観評価に基づく作業効率 (社員)

れたため、各階を図 3 に示すように 8 ゾーン注 ${ }^{10}$ に分け、ゾーン毎 の平均室内温度を算出した。ゾーン毎の室内温度の測定結果を表 5 に示す。表 5 の值も執務時間である 9 時〜 17 時の平均值である。

\section{6. 社員を対象とする被験者実験の結果}

\section{1 主観評価に基づく作業効率の結果}

本検討範囲内において $\mathrm{CO}_{2}$ 濃度は、室内温度と作業効率の関係に

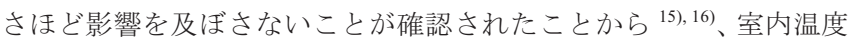


に着目した検討を行う。室内温度が作業効率に与える影響の傾向を 大概的に把握するため、表 4 の物理環境の階平均結果を元に、 $4 \mathrm{~F} の$ 7/25 の被験者と $5 \mathrm{~F}$ の $8 / 1$ の被験者の申告結果を併せたケースを(1) 室内温度 $25.0^{\circ} \mathrm{C}$ の条件、4F の $8 / 1$ の被験者と $5 \mathrm{~F}$ の $7 / 25$ の被験者を 併せたケースを(2) 室内温度 $27.5^{\circ} \mathrm{C}$ の条件 ${ }^{111}$ として温熱環境が作業 効率に及ぼす影響の比較を行う。このような比較ケースを設定する ことで習熟度の差、外気条件、環境曝露の順番の差による影響を排 除した。社員の主観評価に基づく作業効率の結果を図 4 に示す。環 境条件が $25.0^{\circ} \mathrm{C}$ から $27.5^{\circ} \mathrm{C}$ に変化することで、主観評価に基づく作 業効率は有意に $4.0 \%$ 低下寸る結果となった $(\mathrm{p}<0.01)$ 。

\section{2 室内温度と主観評価に基づく作業効率の関係}

続いて室内温度の空間分布を考慮し、室内温度が作業効率に与え る影響を詳細に検討するために、社員を図 3 に示寸 8 ゾーンで分類 し、各ゾーンにおける室内温度とそれに対応する被験者群の作業効 率を算出した。室内温度と主観評価に基づく作業効率の関係を図 5 に示す。各実験ケース、各階、各ゾーンにつき 1 プロットを表す。 ここで、一元配置の分散分析により各プロット間の有意な差 $(\mathrm{p}<0.05)$ を確認している。室内温度と主観評価に基づく作業効率の間に(1) 式で表される有意な相関が得られた $\left(\mathrm{R}^{2}=0.22, \mathrm{p}<0.01\right)$ ここで、室内 温度 $\theta\left[{ }^{\circ} \mathrm{C}\right]$ 、作業効率 $x[\%]$ とする。作業効率が最大になるのは $25.7^{\circ} \mathrm{C}$ であった。

$$
x=-1.383 \theta^{2}+70.991 \theta-825.713 \quad \cdot \cdot \cdot(1)
$$

\section{7. 学生を対象とする被験者実験の結果}

\section{1 主観評価に基づく作業効率の結果}

社員の場合と同様に(1) 室内温度 $25.0^{\circ} \mathrm{C}$ 、(2) 室内温度 $27.5^{\circ} \mathrm{C}$ 条 件で比較を行った。学生被験者の主観評価に基づく作業効率の結果 を図 6 に示す。環境条件が $25.0^{\circ} \mathrm{C}$ から $27.5^{\circ} \mathrm{C}$ に変化することで、主 観評価に基づく作業効率は $4.1 \%$ 低下寸る結果となった $(\mathrm{p}<0.01)$ 。

\section{2 客観評価に基づく作業効率の結果}

客観評価に基づく作業効率の結果を図 7 に示寸。比較条件は主観 評価に基づく作業効率と同様に(1) 室内温度 $25.0^{\circ} \mathrm{C}$ 、(2) 室内温度 $27.5^{\circ} \mathrm{C}$ であり、環境条件が $25.0^{\circ} \mathrm{C}$ から $27.5^{\circ} \mathrm{C}$ に変化することで、加 算作業では有意に $4.1 \%$ 低下寸る結果となった $(\mathrm{p}<0.02)$ 。校正作業、 タイピングでも同様に低下寸る傾向が確認された。

\section{3 室内温度と作業効率の関係}

室内温度が作業効率に与える影響を把握するために、各実験ケー スの室内温度とそれに対応する被験者群の作業効率の関係を検討し た。室内温度と主観評価に基づく作業効率の関係を図 8 に示す。各 実験ケース、各階につき 1 プロットを表す。室内温度と主観評価に 基づく作業効率の間に有意な相関が得られた $\left(\mathrm{R}^{2}=0.73, \mathrm{p}<0.05\right)$ 。結果 より、作業効率が最大になるのは $26.0^{\circ} \mathrm{C}$ であった。また、室内温度 と客観評価に基づく作業効率(3 種の作業の正規化パフォーマンスの 平均) の間にも相関傾向が見られた $\left(\mathrm{R}^{2}=0.62\right.$, n.s. $)$ 。

\section{4 作業効率の主観評価と客観評価の整合性}

作業効率の主観評価と客観評価の関係を図 9 に示寸。客観評価は 3 種の作業の正規化パフォーマンスの平均より算出した。各実験ケ ース、各階、各ゾーンにつき 1 プロットを表す。主観評価と客観評 価の間に有意な相関が得られた $\left(\mathrm{R}^{2}=0.82, \mathrm{p}<0.01\right)$ この結果より、今

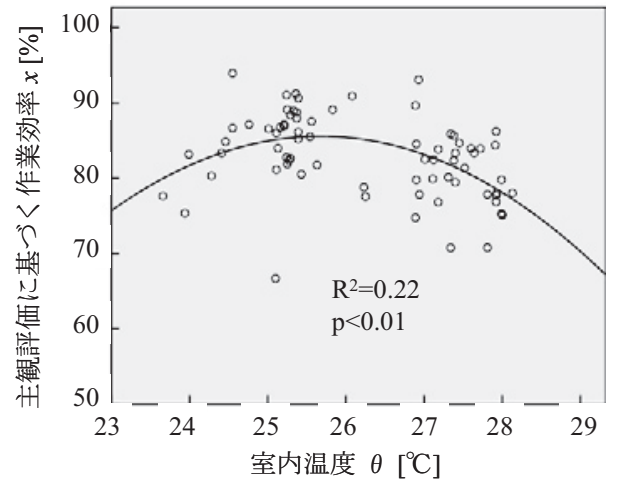

図 5 室温と主観評価に基づく作業効率の関係 (社員)

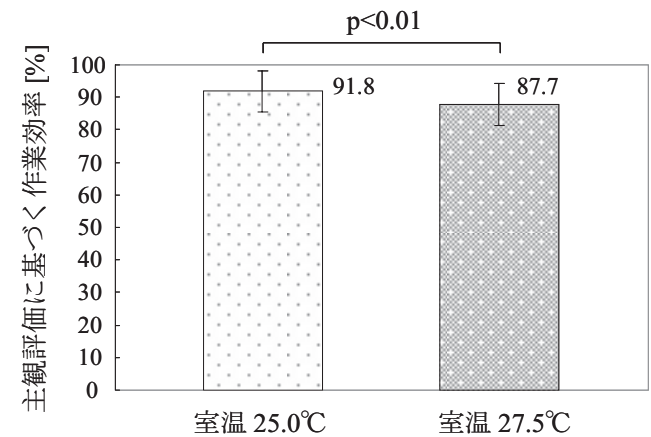

図 6 主観評価に基づく作業効率 (学生被験者)

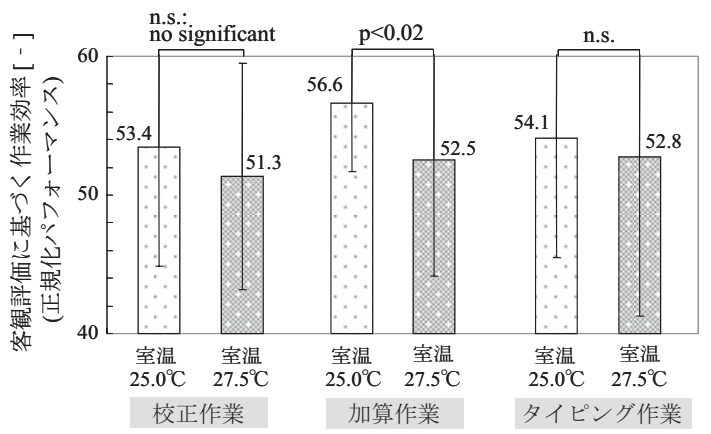

図 7 客観評価に基づく作業効率 (学生被験者)

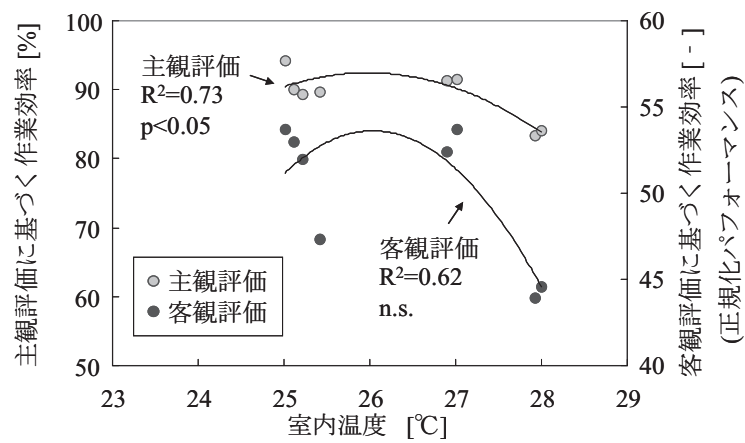

図 8 室温と作業効率の関係 (学生被験者)

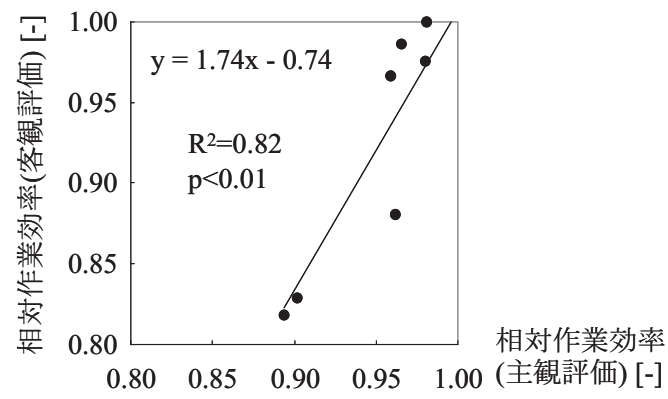

図 9 作業効率の主観評価と客観評価の整合性 
回の検討における主観評価は、十分に信頼できる結果であると判断 できるため、9 節以降の分析には多くのデータ数が確保できた社員 の主観評価に基づく作業効率の結果を用いることとする。

\section{8. 空調用電力消費量の測定結果}

\section{1 調査期間中の空調用電力消費量の測定結果}

各階における空調エネルギー消費量の日積算值と、その内訳とし て、冷温熱源設備の電力消費量ならびに空気搬送用の電力消費量の 日積算值を図 10 に示寸。室内温度の設定条件が $25^{\circ} \mathrm{C}$ と $28^{\circ} \mathrm{C}$ の各ケ 一スについて、 $4 \mathrm{~F}$ と $5 \mathrm{~F}$ で空調エネルギー消費量を比較する。

室内温度の設定条件が $25^{\circ} \mathrm{C}$ のースについて、図 10 (a)に示した $4 \mathrm{~F}$ の空調用電力消費量の測定結果は、 1 週目の測定ケースでは、 565 土42[kWh/日]、3 週目では、631 26 [kWh/日]であった。一方、図 10(b) に示した 5F では、2 週目では、402 $477[\mathrm{kWh} /$ 日]、4 週目では、495 $\pm 31\left[\mathrm{kWh} /\right.$ 日]であった。室内温度が $25^{\circ} \mathrm{C}$ のき、空調エネルギー消 費量は同じ室温設定であるにも関わらず、 $5 \mathrm{~F}$ において $4 \mathrm{~F}$ より 70 〜 $229\left[\mathrm{kWh} /\right.$ 日] 低い結果となった。室内温度の設定条件が $28^{\circ} \mathrm{C} の$ ケ スについて、図 10(a)に示した $4 \mathrm{~F}$ の空調エネルギー消費量の測定結 果は、2 週目の測定ケースでは、199 $26[\mathrm{kWh} /$ 日]、4 週目では、380 土94[kWh/日]であった。一方、図 10(b)に示した 5F では、1 週目は、 $274 \pm 17[\mathrm{kWh} /$ 日]、3 週目は、290土48[kWh/日]であった。室内温度 が $28^{\circ} \mathrm{C}$ のと、空調エネルギー消費量は、 $4 \mathrm{~F}$ の 4 週目、 $5 \mathrm{~F}$ の 3、1 週目、4Fの 2 週目の順に測定值が高い結果となり、 $5 \mathrm{~F}$ において $4 \mathrm{~F}$ の 4 週目より $89 〜 106[\mathrm{kWh} /$ 日]少ない結果となった。

これらの一因として、外気温の影響が考えられる。外気温の 1 週 間の平均值注 ${ }^{12}$ は、1 週目から順に $24.4 \pm 1.4^{\circ} \mathrm{C}(60.6[\mathrm{~kJ} / \mathrm{kg}]) 、 22.4 \pm$ $2.6^{\circ} \mathrm{C}(54.4[\mathrm{~kJ} / \mathrm{kg}]) 、 27.3 \pm 2.2^{\circ} \mathrm{C}(70.5[\mathrm{~kJ} / \mathrm{kg}]) 、 26.3 \pm 2.8^{\circ} \mathrm{C}(67[\mathrm{~kJ} / \mathrm{kg}])$ であった。同じ設定温度でも空調エネルギー消費量に違いが出た要 因が、外気条件であることが示される結果となった。

\section{2 室内温度と空調用電力消費量の関係}

前項で得られた空調用電力消費量の測定結果より、説明変数を室 内温度と外気エンタルピー、目的変数を空調機 1 台あたりの空調用 電力消費量とした 3 次元応答曲面モデルを作成し注 ${ }^{13)}$ 、室内温度 · 外気エンタルピーの平面に写像した結果を図 11 に示す。空調用電力 消費量は、6.2 項で得られた作業効率が最大となる室内温度 $25.7^{\circ} \mathrm{C}$ のとき $90 \sim 110\left[\mathrm{kWh} /\right.$ 日]、室内温度 $28.0^{\circ} \mathrm{C}$ のとき $30 \sim 70[\mathrm{kWh} /$ 日]で あり、室内温度 $25.7^{\circ} \mathrm{C}$ 条件において空調用電力消費量は外気条件を 考慮して、40〜60[kWh/日]余分に消費する結果となった。図 11 で得 られた結果から、外気エンタルピーが測定期間の平均值である $70.3[\mathrm{~kJ} / \mathrm{kg}]$ のときの、室内温度と空調機 1 台あたりの空調用電力消 費量の関係を検討した。室内温度 $\theta\left[{ }^{\circ} \mathrm{C}\right]$ と空調用電力消費量 $e[\mathrm{kWh} /$ 日]の関係は(2)式で表される。

$$
e=-25.3 \theta+758 \quad \cdots \cdot(2)
$$

\section{9. 室内温度と作業効率 · 空調用電力消費量の関係}

作業効率の向上による利益と作業効率向上のための建物運用の関 連付けを、金額換算值を用いて行う。現地調査により得られた関係 式を用い、室内環境の質が作業効率・電力消費量に与える影響を検 討する。

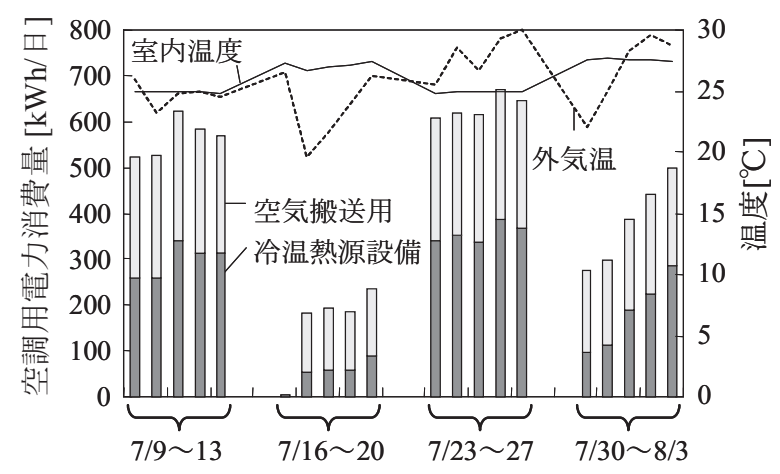

(a) $4 \mathrm{~F}$ の空調エネルギー消費量の日積算值と内訳

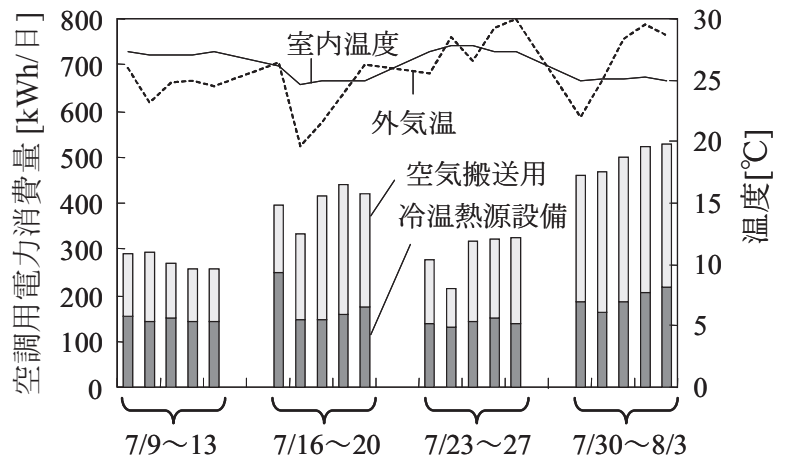

(b) $5 \mathrm{~F}$ の空調エネルギー消費量の日積算值と内訳

図 10 空調用電力消費量の結果

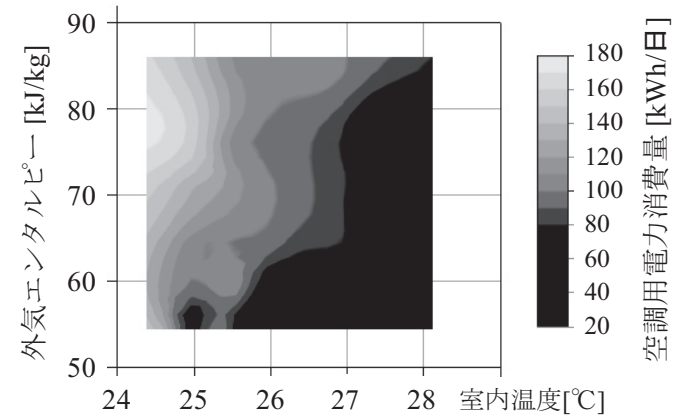

図 11 室内温度と外気エンタルピー、空調用電力消費量の関係

\section{(1) 作業効率の変化による経済的影響の算出}

作業効率の低下は、人件費のロスにつながると考えることができ る。そこで、室内温度が変化したときの作業効率の変化による経済 的影響を(1)式及び(3)式より算出した。

作業効率の変化による経済的影響[円 $/ \mathrm{m}^{2} /$ 日]

$=$ 人件費 $[$ 円 $/$ 人日 $] \times$ 人員密度 $\left[\right.$ 人 $\left./ \mathrm{m}^{2}\right] \times$ 作業効率の低下率 $[\%] \quad \cdots(3)$

尚、人件費は労働経済白書 ${ }^{177}$ による 2007 年の現金給与総額(月額) である 33 万 313 円並びに、2007 年の労働時間 1808 時間を用い、 1 日の労働時間 8 時間分注 14$)$ の人件費 $[$ 円/人/日]を算出し用いた。また、 人員密度は調查対象オフィスの $4 \mathrm{~F} 、 5 \mathrm{~F}$ の平均をとり、0.12[人 $\left./ \mathrm{m}^{2}\right]$ とした。

\section{(2) 空調用電力消費量の変化による経済的影響の算出}

室内温度を上昇させることによる空調用電力消費量の減少は、電 力消費分のエネルギー費用のセーブにつながると考えることができ る。そこで、室温が変化したときの空調用電力消費量の変化による 経済的影響を(2)式及び(4)式より算出した。 
電力消費量の変化による経済的影響 $\left[\right.$ 円 $/ \mathrm{m}^{2} /$ 日]

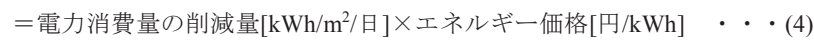

尚、エネルギー価格[円/kWh]は東京電力が設定している夏季の業 務用電力の電力量料金 $11.38[$ 円 $/ \mathrm{kWh}$ ]を用いた。

\section{(3) 作業効率及び空調用電力消費量の変化による経済的影響の結果}

作業効率及び空調用電力消費量の変化による経済的影響の算出結 果を図 12 に示寸。作業効率、空調用電力消費量共に、6.2 項で得ら れた作業効率が最大となる室内温度 $25.7^{\circ} \mathrm{C}$ を基準としたときの変化 を算出した。左軸と右軸のスケールの差から明らかであるように、 空調用電力消費量の変化による経済的影響は作業効率の変化による 経済的影響よりはるかに小さくなる結果となった。そのため、両者 の経済的影響を統合した結果は、図 12 中の作業効率の変化による経 済的影響とほぼ重なり、経済性から判断する最適室内温度は $25.7^{\circ} \mathrm{C}$ となった。

\section{0. 考察}

\section{1 室内温度と作業効率の関係に関する既往研究との比較}

6.2 項より、室内温度と作業効率の間に $25.7^{\circ} \mathrm{C}$ において作業効率 が最大となる二次曲線が得られた。Seppänen ら ${ }^{4)}$ の提案する関係式

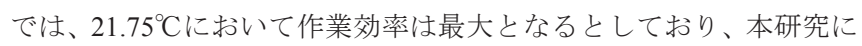
おける作業効率最大の室内温度は、欧米の結果よりかなり高い結果 になったと言える。しかし、村上ら ${ }^{2)}$ の教室の温熱・空気環境が学 習効率に及ぼす影響の検討では、作業効率が最大となる室内温度は、 現地調查では $24.4^{\circ} \mathrm{C}$ 、実験室実験では $24.8^{\circ} \mathrm{C}$ とており、本研究に おける作業効率最大の室内温度と近い值である。このことから、作 業効率を最大とする室内温度は欧米人と日本人で異なることが示唆 される。これらの結果の信頼性の確保のため、引き続き日本人を対 象とした実験や実測を実施し、データを蓄積する必要があると考え られる。

10.2 作業効率最大となる室内温度の被験者属性間の差に関する考察

6 節及び 7 節の結果より、社員と学生被験者の、室内温度と作業 効率の関係の傾向は非常に類似しているが、作業効率が最大になる のは社員では $25.7^{\circ} \mathrm{C}$ 、学生被験者は主観評価・客観評価共に $26.0^{\circ} \mathrm{C}$ であり、社員の方が $0.3^{\circ} \mathrm{C}$ 涼しい側において作業効率が最大となっ た。作業効率が最大となる室内温度の差には、被験者心理や在席率 の相違が影響していることが示唆される。在席率の相違が作業効率 に与える影響に関する考察により ${ }^{18)}$ 、在席率の低い社員の結果が、 全体の結果に影響を与え、環境条件が $25.0^{\circ} \mathrm{C}$ から $27.5^{\circ} \mathrm{C}$ に変化した 時の社員の作業効率の低下を大きくしていることが明らかになった。 これより、在席率が高い学生被験者に比べ、在席率が低い社員の方 が温熱環境へ対する意識が高く、 $2.5^{\circ} \mathrm{C}$ 上昇をより敏感に感じてい ると考えることができる。

\section{1. まとめ}

(1) 社員を対象とした被験者実験において、環境条件が $25.0^{\circ} \mathrm{C} か ら$ $27.5^{\circ} \mathrm{C}$ に変化することで、主観評価に基づく作業効率は有意に $4.0 \%$ 低下寸る結果となった $(\mathrm{p}<0.01)$ 。また、室内温度と主観評 価に基づく作業効率の間に有意な相関が得られた $\left(\mathrm{R}^{2}=0.22\right.$, $\mathrm{p}<0.01)$ この回帰式より、作業効率が最大になるのは $25.7^{\circ} \mathrm{C} て ゙$

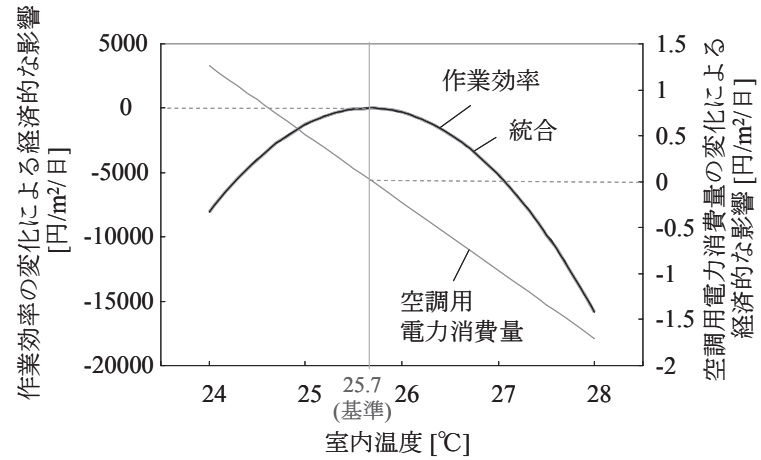

図 12 作業効率及び空調用電力消費量の変化による経済的影響

あった。

(2) 学生被験者を対象とした被験者実験において、環境条件が $25.0^{\circ} \mathrm{C}$ から $27.5^{\circ} \mathrm{C}$ に変化することで、主観評価に基づく作業効率 は 4.1\%低下 $(\mathrm{p}<0.01)$ 、客観評価に基づく作業効率における加算 作業は有意に $4.1 \%$ 低下寸る結果となった $(\mathrm{p}<0.02)$ 。また、室内 温度と主観評価に基づく作業効率の間に有意な相関が得られた $\left(\mathrm{R}^{2}=0.73, \mathrm{p}<0.05\right)$ この回帰式より、作業効率が最大になるのは $26.0^{\circ} \mathrm{C}$ であった。

（3）学生被験者を対象とした被験者実験において、主観評価に基づ く作業効率と客観評価に基づく作業効率の間に $\mathrm{R}^{2}=0.82$ の有意 な相関が得られた $(\mathrm{p}<0.01)$ 。この結果より、今回の検討におけ る主観評価は、十分に信頼できる結果であると判断できる

(4) 空調用電力消費量は、作業効率が最大となる室内温度 $25.7^{\circ} \mathrm{C}$ の とき $90 \sim 110\left[\mathrm{kWh} /\right.$ 日]、室内温度 $28.0^{\circ} \mathrm{C}$ のき $30 \sim 70[\mathrm{kWh} /$ 日] であり、室内温度 $25.7^{\circ} \mathrm{C}$ 条件において空調用電力消費量は外気 条件を考慮して、40～ $60[\mathrm{kWh} /$ 日]余分に消費する結果となった。

(5) 作業効率の変化による経済的影響と空調用電力消費量の変化に よる経済的影響を統合した影響は、作業効率の変化による経済 的影響とほぼ同一のものとなり、経済性から判断する最適室内 温度は $25.7^{\circ} \mathrm{C}$ とっった。

\section{謝辞}

本報は、国土交通省の平成 19 年度住宅・建築関連先導技術開発助 成事業「学習機能に基づく省エネ性と快適性の最適化制御技術の開 発」(応募者: 慶應義塾大学伊香賀研究室、株式会社山武)」の一部で ある。本研究における調查の実施にあたりご協力頂いた方々に心よ り御礼申し上げます。また被験者としてご協力して下さった方々に 感謝致します。 


\section{参考文献}

1) 村上周三: 知的生産性研究の展望, 特集 ワークプレイスプロダクティビ ティ, 空気調和・衛生工学, 第 81 巻, pp.3-8, 2007.1

2) 村上周三, 伊藤一秀, ポール ワルゴッキ: 教室の環境と学習効率, 建築資 料研究社, pp44-108, 2007.10

3) 羽田正沖, 西原直枝, 中村駿介, 内田智志, 田辺新一: 夏季室温緩和設定才 フィスにおける温熱環境実測及び執務者アンケート調査による知的生産 性に関する評価, 日本建築学会環境系論文集, 第 74 巻, 第 637 号, pp.389-396, 2009.3

4) O. Seppänen, W.J.Fisk, and Q.H.Lei: Effect of temperature on task performance in office environment, Proceedings of the $5^{\text {th }}$ International Conference on Cold Climate HVAC, in CD-ROM, 2006.5

5) O. Seppänen, W.J.Fisk, and Q.H.Lei: Ventilation and performance in office work, Indoor Air, Vol.16, pp.28-36, 2006.2

6) 寺野真明, 橋本哲, 杉浦敏浩, 中村政治, 川瀬貴晴, 近藤靖史: 室内環境の 改善によるプロダクティビティ向上に関する調査研究 (第 2 報) プロダク ティビティの測定・評価方法, 空気調和・衛生工学会学術講演会講演論文 集 I ,pp.653-656, 2003.9

7) 地球温暖化対策大綱, 環境省, p.52, 2002

8) 環境省編: 平成 19 年度版 環境白書・循環型社会白書, ぎょうせい, p.36, 2007

9) D.P.Wyon: The effects of indoor air quality on performance and productivity, Indoor Air 2004, 14(Suppl 7), pp.92-101, 2004

10) Olli Seppanen, PE William J. Fisk, PE David Faulkner.: Control of Temperature for Health and Productivity in Offices, ASHRAE Transactions, 2005.8

11) 内田匠子, 亀田健一, 村上周三, 伊香賀俊治, 林立也: クールビズを実践 するオフィスにおける扇風機の気流が作業効率に及ぼす影響，日本建築 学会大会学術講演梗概集, D- II , pp.1169-1170, 2007.8

12) 羽田正沖, 西原直枝, 田辺新一: 知的生産性によるオフィスの温熱環境の 経済的影響評価，日本建築学会大会学術講演梗概集，D- II，pp.455-458, 2006.9

13) REHVA: オフィスにおける室内気候と知的生産性, 空調衛生工学会, pp. $35-40,2008.8$

14) 杉浦敏浩, 橋本哲, 寺野真明, 中村政治, 近藤靖史, 川瀬貴晴, 杉浦敏浩: 室内環境の改善によるプロダクティビティ向上に関する調査研究(第 7 報), 主観的評価法の標準化に向けた検討, 空気調和・衛生工学会論文集 I, pp.2057-2060, 2005.8

15) 内田匠子, 伊香賀俊治, 村上周三, 三枝隆晴, 上田悠, 多和田友美：才フ イスの知的生産性と省エネルギー性を考慮した最適空調制御手法の研究, 空気調和・衛生工学会学術講演会講演論文集 I , pp.1995-1998, 2008.8

16) 内田匠子, 伊香賀俊治, 村上周三, 亀田健一, 多和田友美, 三枝隆晴, 上 田悠: 実オフィスの室内環境が知的生産性に及ぼす影響(その 2) 室温・ $\mathrm{CO}_{2}$ 濃度と作業効率の関係の 3 変数を可視化した検討, 日本建築学会大 会学術講演梗概集, D- II , pp.1145-1146, 2008.9

17) 厚生労働省: 労働経済白書 平成 20 年度版 -働く人の意識と雇用管理の 動向-, p.36, 2008.7

18）多和田友美，伊香賀俊治，村上周三，亀田健一，内田匠子，三枝隆晴，上 田悠: 実オフィスの室内環境が知的生産性に及ぼす影響(その 1) 被験者属 性別の温熱環境と作業効率の関係, 日本建築学会大会学術講演梗概集, DII , pp.1143-1144, 2008.9

\section{注}

注 1) ワーカーのモチベーション・体調等が安定していると考えられる週の中 日である水曜日とした。

注 2) 常設の温度センサと、実験のため設置した機器による温度測定結果は概 ね一致し、整合性は確認できた。

注 3) 冷温熱源設備の電力消費量 $=$ 冷温水生成に消費する電力量 $[\mathrm{kWh}$ (4) $\times$ 冷水積算熱量 $[\mathrm{MJ}]($ (1) $) /$ 冷水積算熱量 $[\mathrm{MJ}]$ (3)

注 4) 空気搬送用の電力消費量 $=$ 送風機電力量 $[\mathrm{kWh}]($ (2) $)+$ 送風機電力量 $[\mathrm{kWh}]($ (5) (※括弧内の数字は表 3 に対応 $)$

注 5) アンケート項目中の、在席率、体調、モチベーションを問う項目の回答 結果を用いたスクリーニングを行い、いずれの比較も両ケース同一の 被験者群(社員 57 名、学生被験者 8 名)を用いている。

注 6) 左右の 5 桁の数字が異なるものにチェックをする PC 上の作業。1 回の 画面では全 20 問あり、異なるもの全てにチェックをつけたと思ったら、
自分で次のページに進めるようになっている。問題は常にランダムに なるように設定している。

注 7) 4 桁と 4 桁の足し算である。問題作成の際の数字は、乱数表によりラン ダムに選定しているため、特に難易度に偏りがないように配慮した。 加算作業は問題用紙を配布し、直接解答を書き込む形式で行った。

注 8）PC の画面に表示された文字にならってタイピングする。文字列は全て アルファベットとし、母音と子音が交互になるようにした。文字列は アルファベットを乱数表に対応させてランダムになるように設定した。

注 9) 表中の $\pm \alpha$ は室内温度、放射温度、相対湿度、 $\mathrm{CO}_{2}$ 濃度については空間 及び時間的ばらつきを、風速については時間的ばらつきを含む標準偏 差を表す。

注 10) 空調機単位である図 1 の点線で区切られた 4 ゾーンの中でも、さらに 3つの VAV に分けて制御を行っている。常設の温度センサはVAVに 対応した測定点に設けられており、同 VAV 内は同グループとした上で このセンサの測定值を用いた。中央部に 2 か所ずつ並ぶセンサの測定 值はほぼ同一であったため、ゾーン 3〜6 を設けるにあたり点線で分け られる南北に分けなかった。また、東西にある空面からの放射の影響 を考慮するため、ゾーン 2 とゾーン 8 を独立させた。

注 11) 表 4 より、8/1の $4 \mathrm{~F}$ の室内温度は $27.5 \pm 0.4^{\circ} \mathrm{C}$ (階平均)、 $7 / 25$ の $5 \mathrm{~F}$ の室 内温度は $27.7 \pm 0.4^{\circ} \mathrm{C}$ (階平均)であったため、 $27.5^{\circ} \mathrm{C}$ のケースと設定した。

注 12) 空調稼働時間である午前 8:00〜午後 8:00における平均值を使用した。

注 13) 応答曲面モデルの作成は、最適設計ツール「dataNESIA」(株式会社 山 武)を使用した。応答曲面モデルとは、システムにおける入力と出力の 因果関係を数学的に多次元で対応付けた近似曲面である。実際に計測 された入出力の離散的データから、そのデータ間の計測されなかった 入出力データを補間し入出力関係をモデル化できる。

注 14) 労働基準法で定められた 1 日当たりの法定基準時間である。

（2009年 6 月 7 日原稿受理，2009年10月26日採用決定） 